\title{
Severity of Depression and Anxiety, and Quality of Sleep and Life in Healthcare Workers During the COVID-19 Pandemic
}

COVID-19 Pandemisi Sırasında Sağlk Çalışanlarının Depresyon ve Anksiyete Şiddeti İle Uyku ve Yaşam Kaliteleri

${ }^{1}$ Onur Serdar Gencler, ${ }^{2}$ Ozgur Demirhan, ${ }^{3}$ Ece Cicek, ${ }^{4}$ Tuba Ertunc, ${ }^{5}$ Asli Enez Darçın, (11)

${ }^{1}$ Yuksek Ihtisas University Faculty of Medicine, Medical Park Ankara Batikent Hospital, Department of Neurology Ankara, Turkey

${ }^{2}$ Private Practice, Internal Medicine, Batikent, Ankara, Turkey

${ }^{3}$ Medical Park Ankara Batikent Hospital, Ankara, Turkey,

${ }^{4}$ Yuksek Ihtisas University, Department of Psychology, Medical Park Ankara Batikent Hospital, Ankara, Turkey

${ }^{5}$ Kanuni Sultan Suleyman Training and Research Hospital, Department of Psychiatry, Istanbul, Turkey

${ }^{6}$ Yuksek Ihtisas University Faculty of Medicine, Department of Neurology, Ankara, Turkey

Correspondence:

Onur Serdar GENÇLER

Yuksek Ihtisas University Faculty

of Medicine, Medical Park Ankara Batikent Hospital, Department of Neurology Ankara, Turkey e-mail:.trserdargencler@gmail.com

\section{Abstract}

The COVID-19 pandemic is having an adverse effect on healthcare workers (HCWs), both physically and mentally, due to the increased workload. The present study evaluates the effects of the COVID-19 pandemic on the level of depression and anxiety, and on quality of sleep and life among HCWs. In this cross-sectional study, an online questionnaire was used to garner data on mental health parameters and quality of sleep in HCWs and non-HCWs. The participants were evaluated with the "Patient Health Questionnaire-9" (PHQ-9) for depressive symptoms, the "Beck Anxiety Inventory" (BAI) for anxiety symptoms, the "Pittsburgh Sleep Quality Index" (PSQI) for sleep quality and the "Professional Quality of Life" (ProQol) scale for quality of life. Included in the study were 543 respondents, comprising 335 HCWs and 208 non-HCWs. The PHQ-9, BAI and PSQI scores were found to be significantly higher in the HCWs than in the non-HCWs. Among the HCW, the PHQ-9, BAI, PSQI and ProQol-compassion satisfaction scores were significantly higher for nurses than for physicians; the BAI, PSQI and ProQol-burnout scores of the nurses were higher than those of non-medical hospital personnel; and the BAI scores of the allied healthcare professionals were higher than those of physicians. The study found HCWs, especially nurses, to be more affected by the COVID-19 pandemic than the public in terms of mental health and sleep quality. During the COVID-19 pandemic, psychological support programs should be provided for HCWs to ensure the maintenance of quality of life among these key personnel.

Keywords:COVID-19 pandemic; healthcare workers; mental health; quality of sleep and life

\section{Özet}

COVID-19 pandemisi, artan iş yükü nedeni ile hem fiziksel hem de zihinsel olarak sağlık çalışanları üzerinde olumsuz bir etkiye sahiptir. Bu çalıșma, COVID-19 pandemisinin, sağlık çalıșanlarının depresyon ve anksiyete düzeyi ile uyku ve yaşam kaliteleri üzerindeki etkilerini değerlendirmektedir. Bu kesitsel çalışmada sağlık çalışanları ve sağlık çalışanı olmayanlarda mental sağlık parametreleri ve uyku kaliteleri ile ilgili verileri elde etmek için çevrimiçi bir anket kullanılmıştır Katılımcılar, depresyon için "Hasta Sağlığı Anketi-9" (PHQ-9), anksiyete semptomları için "Beck Anksiyete Envanteri” (BAE), uyku kalitesi için "Pittsburgh Uyku Kalitesi indeksi” (PUKİ) ve yaşam kalitesi için "Çalışanlar için Yaşam Kalitesi Ölçeği”" (ProQol) ile değerlendirilmiştir. Çalışmaya 335'i sağlık çalışanı ve 208'i sağlık çalışanı olmayan toplam 543 kişi dahil edildi. PHQ-9, BAE ve PUKİ skorları sağlık çalıșanlarında, sağlık çalıșanı olmayanlara göre anlamlı derecede yüksek bulundu. Sağlık çalıșanları arasında PHQ-9, BAE, PUKİ ve ProQol-mesleki tatmin skorları, hemşirelerde doktorlara göre anlamlı derecede daha yüksekti; hemşirelerin BAE, PUKİ ve ProQol-tükenmişlik skorları tıbbi olmayan hastane personeline göre daha yüksekti ve yardımcı sağlık personellerinin BAE skorları ise doktorlardan daha yüksekti. Bu çalışmada, sağlık çalışanlarının, özellikle de hemşirelerin, COVID-19 pandemisinden mental sağlık ve uyku kalitesi yönünden topluma göre daha çok etkilendiği saptanmıştır. COVID-19 pandemisi esnasında, bu kilit personelin yaşam kalitesinin sürdürülmesini temin etmek için, sağlık çalıșanlarına psikolojik destek programları sağlanmalıdır.

Anahtar Kelimeler: COVID-19 pandemisi; sağlık çalışanları; mental sağlık; uyku ve yaşam kalitesi 


\section{Introduction}

Coronavirus disease 2019 (COVID-19) began in the city of Wuhan in the Hubei Province of China, and spread rapidly around the world in a short time. The causative agent was named severe acute respiratory syndrome coronavirus-2 (SARS-CoV-2) $(1,2)$ and on March 11, 2020, the outbreak was declared a pandemic by World Health Organization (3).

In such outbreaks of disease in recent years, such as SARS and Ebola, numerous psychiatric symptoms were observed among the public $(4,5)$. Similarly, the increased threat of infection associated with COVID-19 has led to a rise in anxiety and depression around the world (6), and the development of these symptoms is likely to lead to posttraumatic stress disorder (PTSD) (7). It is known from previous experience that infectious disease outbreaks can affect the mental health of societies, and can impair sleep quality in individuals (8).

The frontline position of healthcare workers (HCWs) in the management of the COVID-19 outbreak places them at increased risk of infection (9-11). Previous studies have established that serious life-threatening outbreaks, such as SARS and Ebola, place considerable pressure on HCWs (12), increasing the likelihood of development of psychological stress and other mental health problems, as well as sleep disorders (9). During the COVID-19 pandemic, various factors, such as risk of nosocomial infection and even mortality due to constant contact with patients, excessive workload, fatigue, lack of personal protective equipment and uncertainties during working hours, were found to have a negative physical and mental impact on healthcare personnel. Personal isolation, reduced social support, the risk of infecting relatives, expectations of support and the sense of responsibility towards the general public elevate the psychological stress level of HCWs and frontline workers in particular, while also increasing their susceptibility to anxiety, depression, PTSD, and sleep problems (11-13).

The primary objective in the present study is to evaluate the severity of depressive and anxiety symptoms, as well as sleep quality, among HCWs in Turkey during the COVID19 pandemic. To the best of our knowledge, there have been few studies to date evaluating quality of life in HCWs related to burnout, PTSD and job satisfaction. Accordingly, as a further objective of the study, HCWs are assessed also in terms of these parameters.

\section{Materials and Methods}

\section{Study design and participants}

This cross-sectional observational study evaluates the mental health parameters, and quality of sleep and life among $\mathrm{HCWs}$ during the COVID-19 pandemic in Turkey. The depression, anxiety and sleep quality scores of the HCWs were compared with those of non$\mathrm{HCW}$ volunteers. The study was conducted between August 1 and September 1, 2020, with the prepared questionnaires being completed online by all participants. The $\mathrm{HCW}$ group in the study comprised HCWs working at Yuksek Ihtisas University Medicalpark Ankara Batikent Hospital, as a sole center. The HCWs who agreed to participate in the study were categorized into four groups: physicians, nurses, allied health professionals (AHPs) (emergency medicine anesthesia-radiology technicians, operating room staff and laboratory personnel) and nonmedical hospital personnel (NMHP) (administrative staff, medical secretaries, cleaning staff). The control group (nonHCWs) included friends of hospital employees, who themselves or their relatives were not HCWs, or relatives of patients who presented to the hospital. The inclusion criteria were: Being over the age of 18 and able to understand and fill out the questionnaires completely. The study was conducted in compliance with the principles of Good Clinical Practice and the Declaration of Helsinki and its amendments, and the study protocol was approved by the Ethics Committee of Yuksek Ihtisas University, with reference number of 2020/07/09. Online informed consent for inclusion in the study was provided by each participant in advance of the study. 


\section{Screening questionnaire}

The first part of the questionnaire garnered details of such basic sociodemographic characteristics and histories of comorbidities. Among the study variables, depression was assessed using the Patient Health Questionnaire-9 (PHQ-9), anxiety using the Beck Anxiety Inventory (BAI), sleep quality using the Pittsburgh Sleep Quality Index (PSQI) and healthcare workers' quality of life using the Professional Quality of Life Scale (ProQol).

The PHQ-9 is a self-reporting questionnaire that is used to aid in the diagnosis and evaluation of the severity of depression (14). The questionnaire includes nine items and evaluates how often the individual has been disturbed by the problem specified in each item over the last two weeks, rated on a fourpoint Likert scale. In the present study, an accepted a cut-off value of 10 points was established, with scores of $\geq 11$ being evaluated as depression. The Turkish reliability study of the questionnaire was conducted by Sari et al. in 2016 (15).

BAI is a 21-item, self-reported, valid and reliable inventory that was developed by Beck et al. in 1988 to measure the severity of anxiety in psychiatric populations (16). The respondents are asked to evaluate the level to which they have been disturbed by the symptoms specified in each item within the last one week on a four-point Likert scale. The validity and reliability study of the Turkish version of BAI was conducted by Ulusoy et al. in 1998 (17).

The PSQI is a self-administered scale that measures an individual's sleep quality within the last one month. The scale consists of 19 items for the assessment of seven parameters, being subjective sleep quality, sleep latency, sleep duration, habitual sleep efficiency, sleep disturbance, hypnotic drugs and daytime dysfunction. Each component is scored from 0 to 3 , and the total score ranges from 0 to 21 points. The higher the score, the poorer the reported sleep quality (18). The present study accepted the cut-off value for PSQI as 7, while a score of $>7$ points indicated sleep disorder (19). The Turkish validity and reliability study of the PSQI was conducted in 1996 (20).

ProQol, the Turkish validity and reliability study of which was conducted by Yesil et al. in 2010, is a self-reported scale that was developed by Stamm BH. The scale consists of three subscales, each of which comprises 10 items [compassion satisfaction (CS), burnout (BO), compassion fatigue (CF secondary traumatic stress scale)], with each subscale being evaluated separately (21).

\section{Statistical analyses}

The statistical analysis was performed using IBM SPSS Statistics (Version 23.0. Armonk, NY: IBM Corp). For descriptive statistics, normal distribution was determined by a OneSample Kolmogorov Smirnov test. Normally distributed continuous variables were expressed as medians (min-max), while categorical variables were expressed in numbers and percentages. A Student's t test was used to compare the continuous variables of two groups, a One-Way Anova was applied for more than two groups, and subgroups were compared with Bonferroni Post-Hoc analyses. The differences between categorical variables were calculated using a Chi-square test. The independent impact of factors on the scores were established with Linear Logistic Regression analyses. A p value of $<0.05$ was considered statistically significant.

\section{Results}

\section{Participants and sociodemographic characteristics}

A total of $543(87.0 \%)$ of the 624 people approached agreed to participate in the study, including $335(86.1 \%)$ of the $389 \mathrm{HCWs}$ and $208(88.5 \%)$ of the 235 non-HCWs. The 81 people who refused to participate in the study or who did not complete the questionnaire in full were excluded. The sociodemographic characteristics and other variables of the HCWs, non-HCWs and HCW subgroups, are presented in Table 1. 


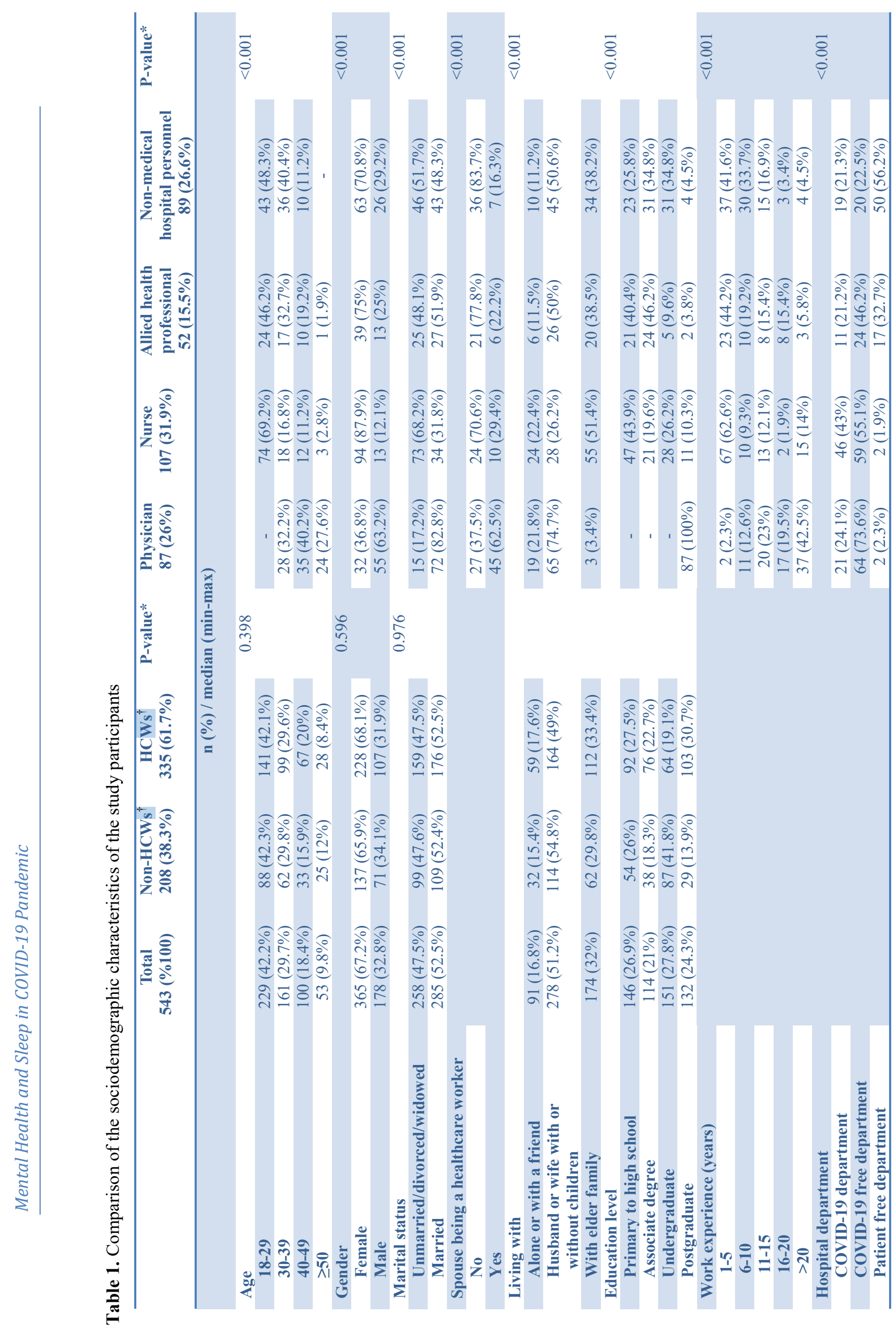



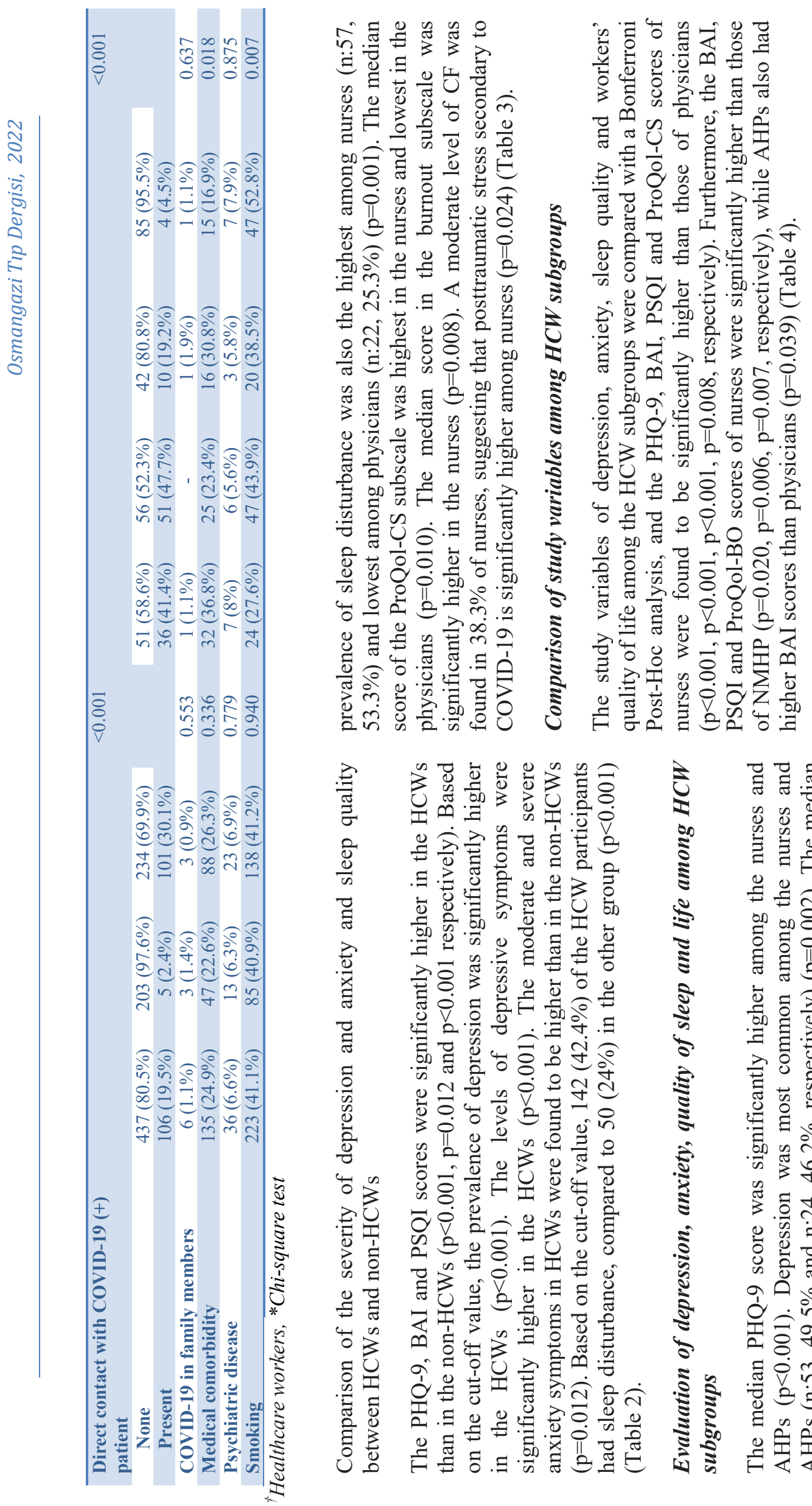

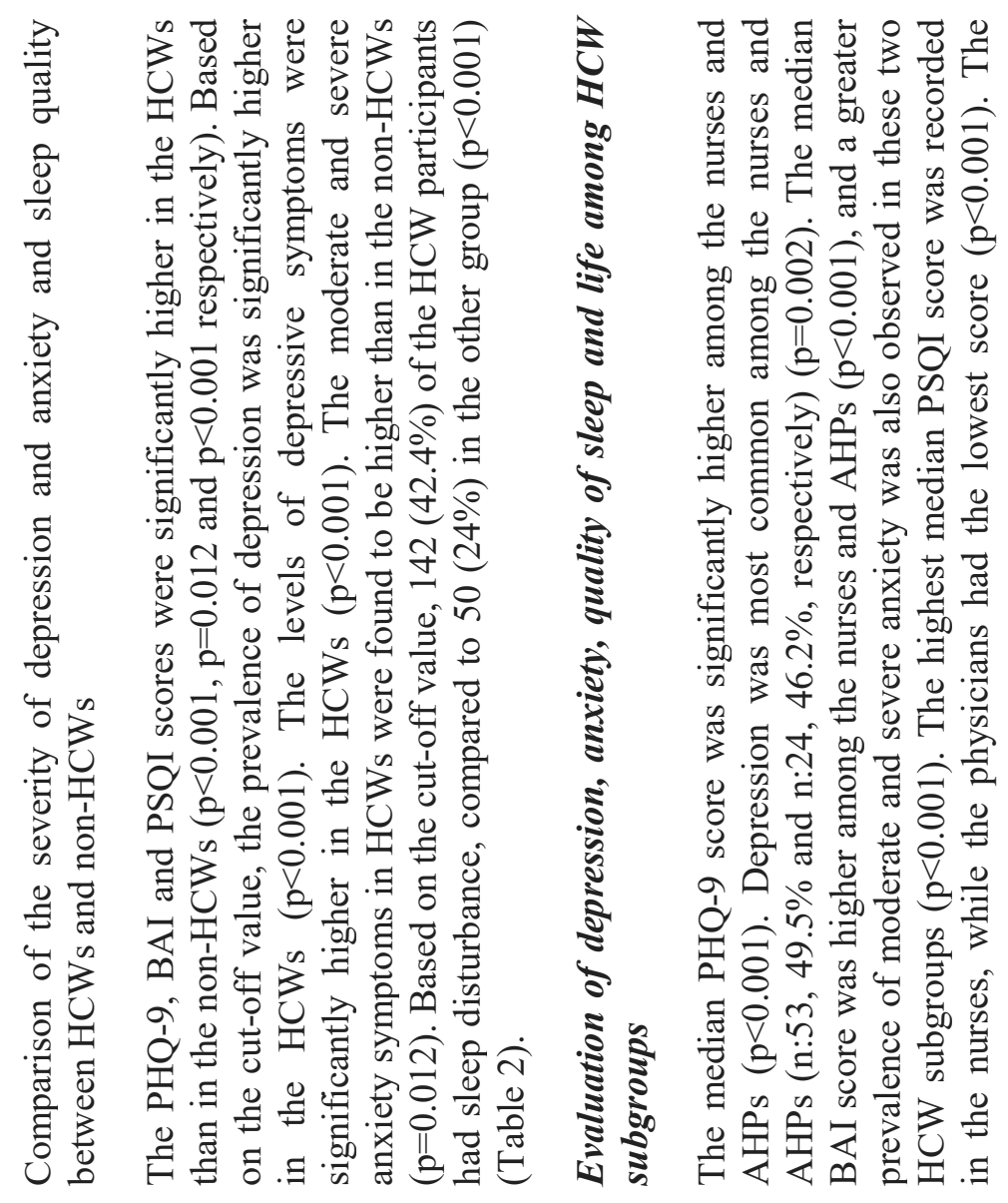


Table 2. Scores and severity of depression, anxiety and sleep quality of HCWs and non-HCWs

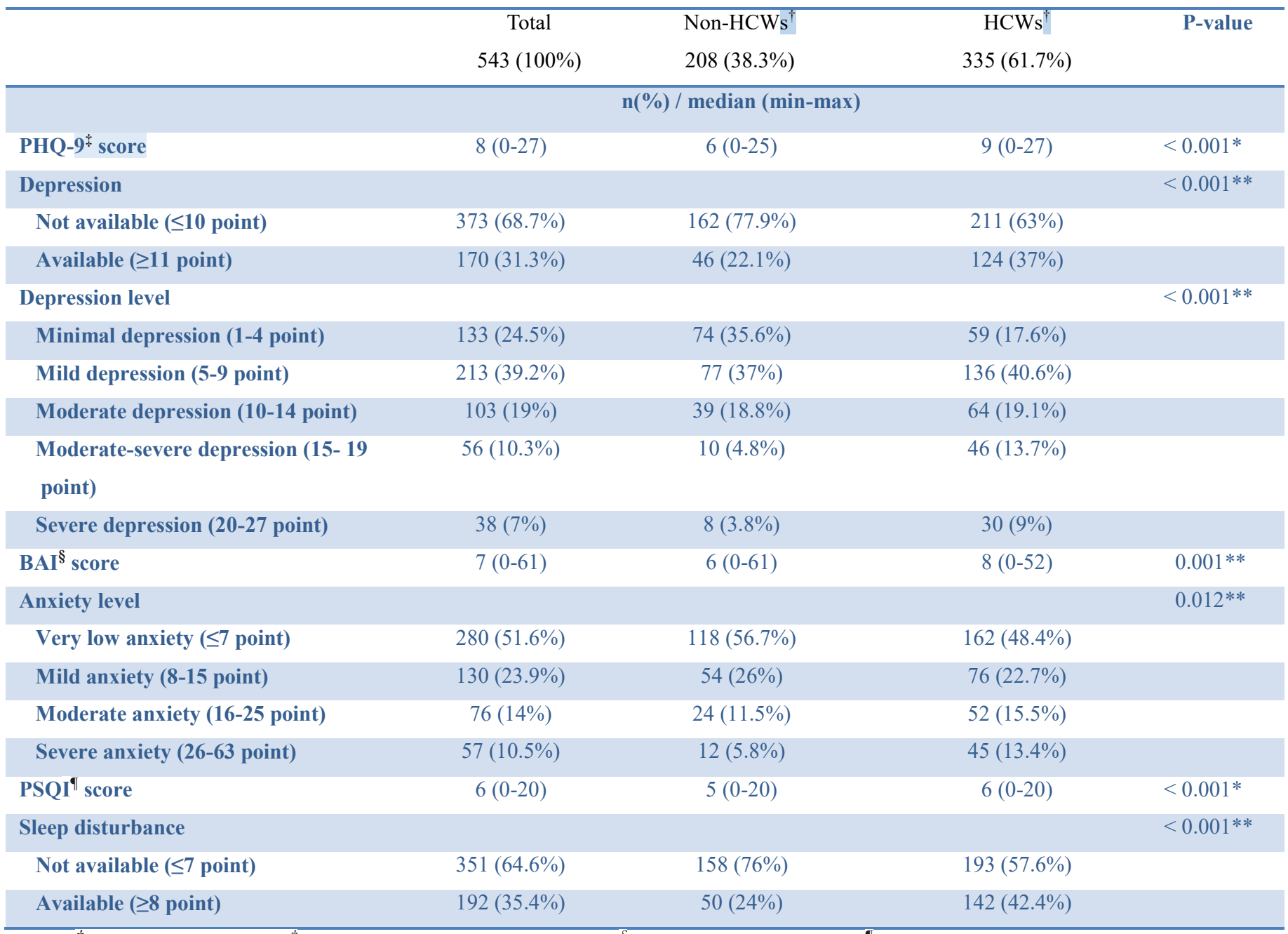

${ }^{\dagger}$ Healthcare workers, ${ }^{*}$ Patient Health Questionnaire-9, ${ }^{\S}$ Beck Anxiety Inventory, "Pittsburgh Sleep Quality Index *Student's t test, **Chi-square test

Table 3. Scores and severity of depression, anxiety, quality of sleep and life among HCW subgroups

\begin{tabular}{|c|c|c|c|c|c|}
\hline & Physician & Nurse & $\begin{array}{l}\text { Allied health } \\
\text { professional }\end{array}$ & $\begin{array}{c}\text { Non-medical } \\
\text { hospital personnel }\end{array}$ & P-value \\
\hline & $87(26 \%)$ & $107(31.9 \%)$ & $52(15.5 \%)$ & $89(26.6 \%)$ & \\
\hline & \multicolumn{5}{|c|}{$\mathrm{n}(\%) /$ median $(\min -\max )$} \\
\hline PHQ-9 ${ }^{\dagger}$ score & $7(0-27)$ & $10(0-27)$ & $10(0-26)$ & $8(0-27)$ & $<0.001^{*}$ \\
\hline Depression & & & & & $0.002 * *$ \\
\hline Not available ( $\leq 10$ point $)$ & $68(78.2 \%)$ & $54(50.5 \%)$ & $28(53.8 \%)$ & $61(68.5 \%)$ & \\
\hline Available ( $\geq 11$ point) & $19(21.8 \%)$ & $53(49.5 \%)$ & $24(46.2 \%)$ & $28(31.5 \%)$ & \\
\hline Depression level & & & & & $<0.001 * *$ \\
\hline Minimal depression (1-4 point) & $25(28.7 \%)$ & $9(8.4 \%)$ & $8(15.4 \%)$ & $17(19.1 \%)$ & \\
\hline Mild depression (5-9 point) & $40(46 \%)$ & $39(36.4 \%)$ & $18(34.6 \%)$ & $39(43.8 \%)$ & \\
\hline Moderate depression (10-14 point) & $13(14.9 \%)$ & $24(22.4 \%)$ & $13(25 \%)$ & $14(15.7 \%)$ & \\
\hline $\begin{array}{l}\text { Moderate-severe depression (15-19 } \\
\text { point) }\end{array}$ & $2(2.3 \%)$ & $22(20.6 \%)$ & $10(19.2 \%)$ & $12(13.5 \%)$ & \\
\hline Severe depression (20-27 point) & $7(8 \%)$ & $13(12.1 \%)$ & $3(5.8 \%)$ & $7(7.9 \%)$ & \\
\hline
\end{tabular}




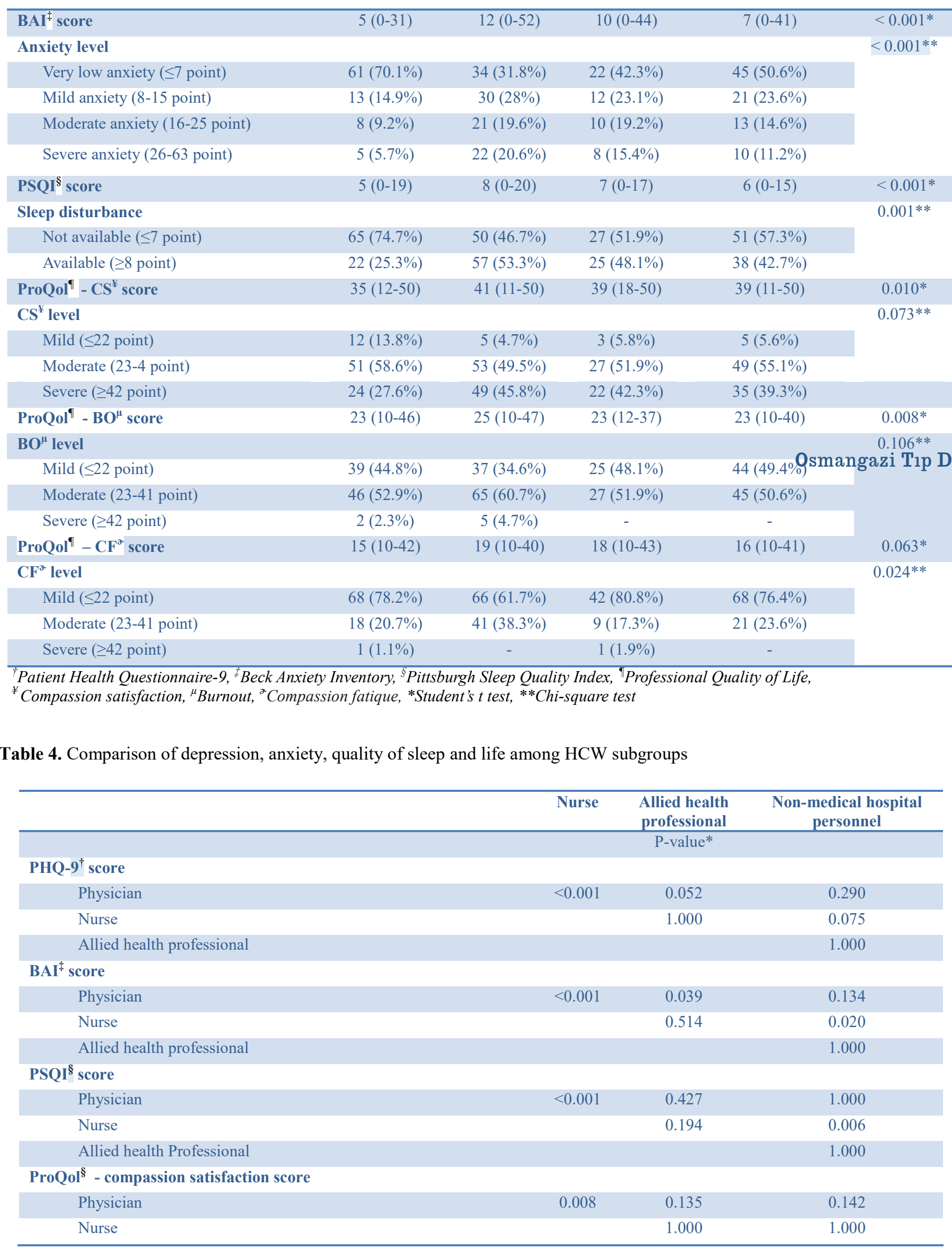




\begin{tabular}{|c|c|c|c|}
\hline Allied health professional & & & 1.000 \\
\hline \multicolumn{4}{|l|}{ ProQol $^{\S}$ - burn-out score } \\
\hline Physician & 0.148 & 1.000 & 1.000 \\
\hline Nurse & & 0.297 & 0.007 \\
\hline Allied health professional & & & 1.000 \\
\hline \multicolumn{4}{|l|}{ ProQol $^{\S}$ - compassion fatigue score } \\
\hline Physician & 0.066 & 1.000 & 1.000 \\
\hline Nurse & & 0.625 & 0.431 \\
\hline Allied health professional & & & 1.000 \\
\hline
\end{tabular}

Independent factors for depression, anxiety, sleep disturbance, $\mathrm{CS}, \mathrm{BO}$ and $\mathrm{CF}$

The study results revealed that younger age, female gender, lower education level, working in units with COVID-19 patients, presence of COVID-19 in family members and history of psychiatric disease to be independent factors for depression. Female gender, lower education level, working in COVID-19 departments and history of psychiatric disease were independent factors for anxiety. Additionally, female gender, working in units with COVID-19 patients, presence of COVID-19 symptoms and history of asthma were found to be independent factors for sleep disturbance. In an examination of quality of life, female gender, direct contact with a SARS-CoV-2 positive patient and a history of psychiatric disease were independent factors for BO. Finally, female gender; being single, divorced or widowed; and working in COVID-19 departments were independent factors for PTSD (Table 5).

\section{Discussion}

$\mathrm{HCWs}$ working on the frontline are at the highest risk of infection during disease outbreaks (12). Studies during the SARS outbreak in 2003 found healthcare personnel to be afraid of transmitting the infection to their families and colleagues, resulting in increased stress, anxiety and depressive symptoms $(22,23)$.

The findings of the present study reveal significantly higher levels of depression and anxiety and disturbed sleep among HCWs during the COVID-19 pandemic than among non-HCWs. The present study identified depression in $37 \%$ and severe anxiety in
$13.4 \%$ of HCWs. While the depression and anxiety levels (50.4\% and $44.6 \%$ respectively) were quite high in a multi-center study conducted in China at the beginning of the pandemic (9), Korkmaz et al. observed severe anxiety in $13 \%$ of HCWs during the current pandemic (24). Another study from China with a large number of participants identified high levels of anxiety and sleep disturbance among HCWs, while HCWs had lower depressive symptoms than non-HCWs (25). The determination of mental health parameters at different rates in the studies conducted during the pandemic may be due to the fact that these studies were carried out in different periods of the pandemic, and the information about COVID-19 was increased in time.

The present study identified disturbed sleep in more than one-third (35.4\%) of the all participants, which may be due to impaired cortisol secretion, decreased melatonin synthesis and increased cortisol levels in the blood as a result of increased anxiety, leading to a reduction in sleep quality in the individual (8). During the COVID-19 outbreak, Lai et al. reported a rate of insomnia of $34.0 \%$ among HCWs (9). In the present study, we observed sleep disturbance (42.4\%) higher in HCWs. Besides sleep disturbance was markedly lower in non-HCW group (24\%) compared to HCWs. This difference can be explained by the limited opportunities for rest associated with increased working hours and the heavier workloads of HCWs, and the elevated psychological distress, as was seen also in the SARS and MERS outbreaks $(26,27)$. 


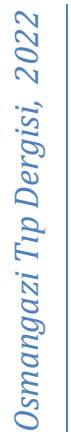

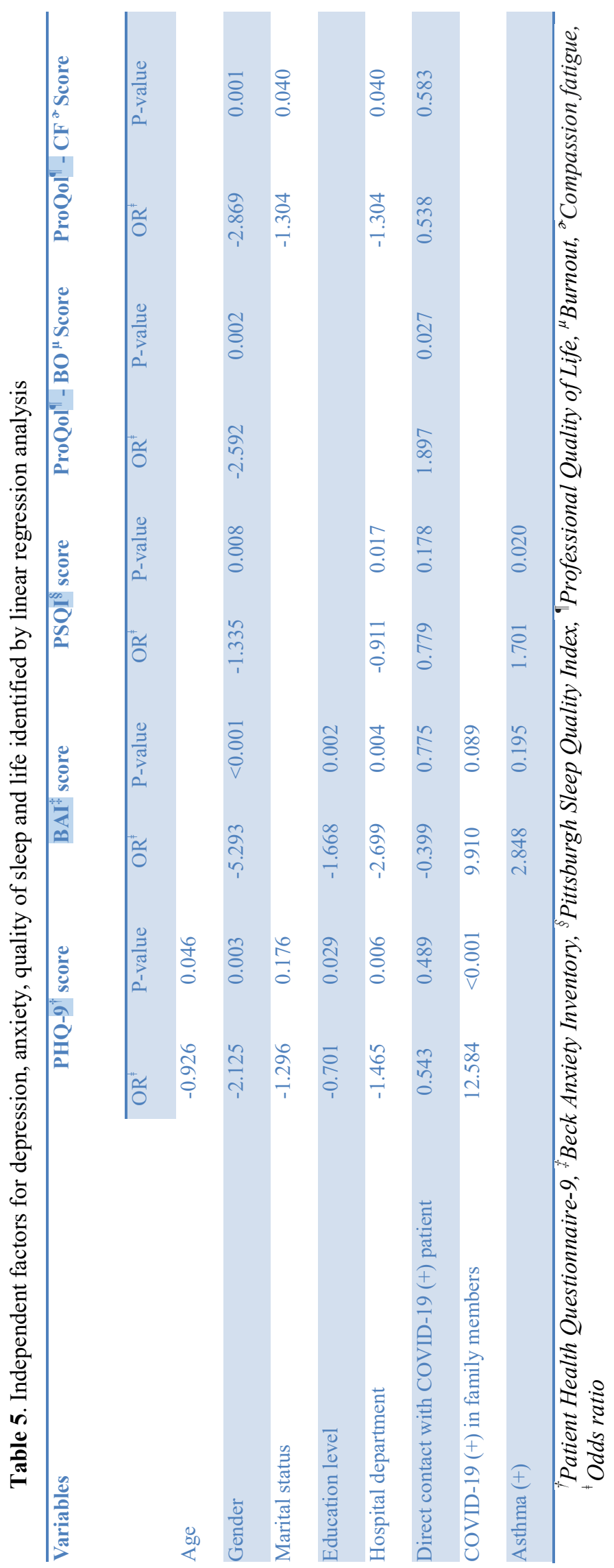

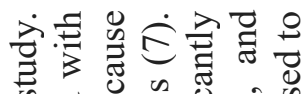

फ

薦劳

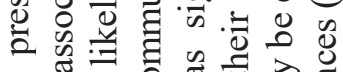

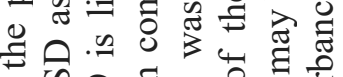

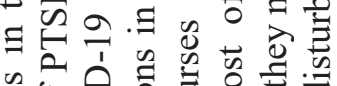

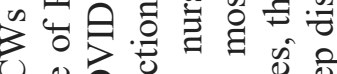

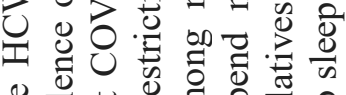

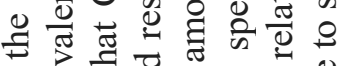

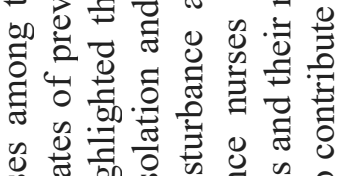

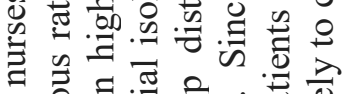

\&

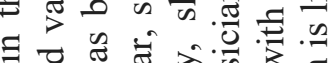

.

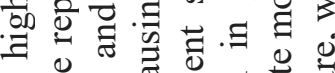

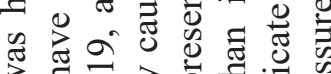

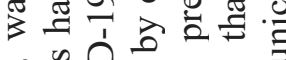

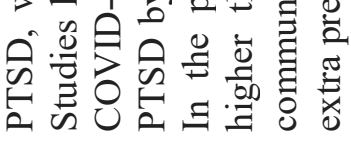

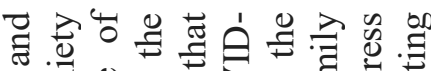

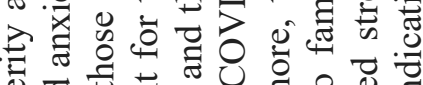

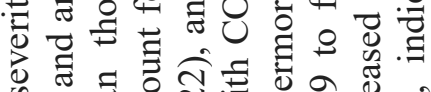

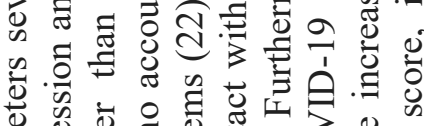

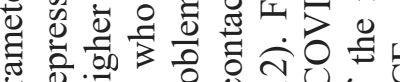
元记

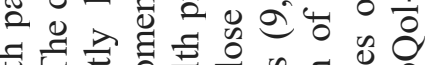

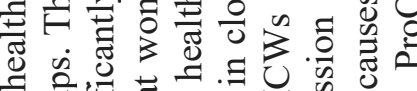
元

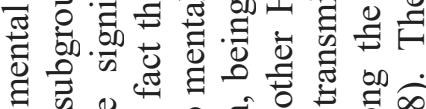
चे च

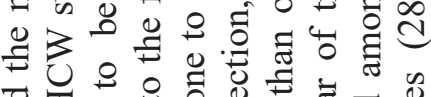
可讨

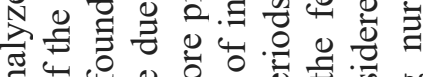
สี 음

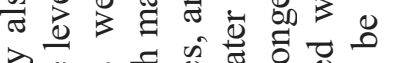

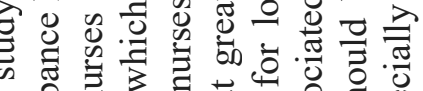

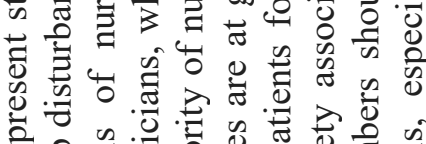

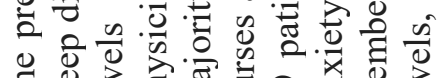

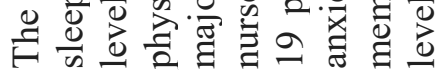


Within the ongoing pandemic, the long working hours of HCWs, the prolonged use of personal protective equipment, dehydration and lack of sleep can cause burnout (29). As expected, burnout was found to be higher among nurses, who usually spend longer periods of time with SARS-CoV-2-positive patients (24) than non-medical personnel, who have no direct contact with the virus. This difference in the level of burnout may be attributable to the fact that non-medical personnel have the option of working less and working remotely (30). Zerbini et al. found that nurses working in COVID-19 wards were more psychologically affected by the pandemic than physicians working under the same conditions, which was attributed to the increased workload of nurses and their prolonged contact with COVID-19 patients (31). Despite these negative factors, it was interesting to note that CS was found to be higher among nurses in the present study. The fact that nurses have been working hard and risking their lives for COVID-19 patients for so long may be appreciated by their relatives and society, resulting in enhanced job satisfaction among nurses (32).

According to the linear regression analysis, young age and COVID-19 positivity among family members were independent factors for depression in this study. This finding can be explained by the fact that young people use social media much more effectively, making them more prone to stress and, having a friend or relative infected with COVID-19 was found to be associated with higher levels of stress, depression and anxiety $(33,34)$. In the present study, the female gender was an independent factor for all scales except CS. The prevalence of depression, anxiety, distress is known to be higher in women than in men $(9,12,35)$, and the female gender is in fact the leading contributory factor to PTSD $(33,35)$. Lower education level was another independent factor for depression and anxiety; and working in units with COVID-19 patients was an independent factor for depression, anxiety, disturbed sleep and CF. A high level of education is believed to have a preventive effect on negative moods, based on autosuggestion, having greater access to information about COVID-19, and in the light of scientific data (35). This may explain why physicians are better able to mentally tolerate the COVID-19 pandemic than other HCWs. PTSD symptoms were more common among the HCWs working in high-risk areas during the SARS outbreak, and negative psychological effects were also detected more in these individuals during the ongoing pandemic (36). Another reason for the higher levels of depression, anxiety, sleep disturbance and PTSD among nurses may be that they spend more time working at the frontline than other HCWs $(9,12)$. People with chronic diseases are more prone to anxiety and insomnia (37). Hence, we found asthma to be associated with sleep disorders. A recent study reported contact with COVID-19 patients to be independently associated with disturbed sleep, and to have the potential to trigger neuropsychiatric symptoms (19), while similarly, contact with SARS-CoV-2 (+) patients was found to be associated with BO in the study. Living alone was identified as an independent factor for PTSD. Most of the nurses included in this study were single, suggesting that they may feel lonely. The understanding that discrimination and loneliness can have negative psychological effects during the current pandemic (34) supports this view.

\section{Limitations}

The present study has several limitations. First, the single-center design of the study and the relatively small sample size limit the generalization of the results to Turkey. Second, the cross-sectional design makes it difficult to predict to what extent the mental health parameters and sleep quality of HCWs, who work under great pressure, will change in the long term. Third, the interviews with most of the study participants were not conducted face-to-face, so as to minimize the risk of COVID-19 infection, with the questionnaires being completed online in a self-administered manner. Finally, the socioeconomic levels of the participants, which could affect the study results, were not taken into account.

\section{Conclusion}

The findings of the present study show that HCWs, and especially nurses, are more affected by the COVID-19 pandemic than the general public in terms of mental health and 
sleep quality. The female gender and working in COVID-19 departments in particular were identified as independent factors for most of the study variables. The ongoing COVID-19 pandemic is seeing increased numbers of patients admitted to hospitals, which, in turn, leads to physical and mental exhaustion in HCWs. This prolonged process can lead to despair, and depression, anxiety, disturbed sleep, burnout and PTSD in HCWs. As can be understood from previous outbreaks, the current outbreak will keep HCWs under its

\section{REFERENCES}

1. Ge H, Wang X, Yuan X, et al. The epidemiology and clinical information about COVID-19. Eur J Clin Microbiol Infect Dis. 2020;39:1011-19.

2. Ahn DG, Shin HJ, Kim MH, et al. Current Status of Epidemiology, Diagnosis, Therapeutics, and Vaccines for Novel Coronavirus Disease 2019 (COVID-19). $J$ Microbiol Biotechnol. 2020;30:313-24.

3. Herman C, Mayer K, Sarwal A. Scoping review of prevalence of neurologic comorbidities in patients hospitalized for COVID-19. Neurology. 2020;95:7784.

4. Shuja KH, Aqeel M, Jaffar A, et al. COVID-19 Pandemic and Impending Global Mental Health Implications. Psychiatr Danub. 2020;32:32-5.

5. Lei L, Huang $X$, Zhang $S$, et al. Comparison of Prevalence and Associated Factors of Anxiety and Depression Among People Affected by versus People Unaffected by Quarantine During the COVID-19 Epidemic in Southwestern China. Med Sci Monit. 2020;26:e924609.

6. Ho CS, Chee CY, Ho RC. Mental Health Strategies to Combat the Psychological Impact of COVID-19 Beyond Paranoia and Panic. Ann Acad Med Singap. 2020;49(3):155-60.

7. Forte G, Favieri F, Tambelli R, et al. COVID-19 Pandemic in the Italian Population: Validation of a Post-Traumatic Stress Disorder Questionnaire and Prevalence of PTSD Symptomatology. Int J Environ Res Public Health. 2020;17:4151.

8. Xiao H, Zhang Y, Kong D, et al. Social Capital and Sleep Quality in Individuals Who Self-Isolated for 14 Days During the Coronavirus Disease 2019 (COVID19) Outbreak in January 2020 in China. Med Sci Monit. 2020;26:e923921.

9. Lai J, Ma S, Wang Y, et al. Factors Associated With Mental Health Outcomes Among Health Care Workers Exposed to Coronavirus Disease 2019. JAMA Netw Open. 2020;3:e203976.

10. Lu W, Wang H, Lin Y, et al. Psychological status of medical workforce during the COVID-19 pandemic: A cross-sectional study. Psychiatry Res. 2020;288:112936. influence for a long time, and so measures should be taken to enhance the motivation and morale of these workers, while non-HCWs should support HCWs through empathy. In order to prevent such negative situations, psychological support programs may be planned for HCWs, and especially for those working at the frontline during the COVID-19 pandemic. This will aid them in maintaining a good quality life, in both the near and distant future.

11. Zhang WR, Wang K, Yin L, et al. Mental Health and Psychosocial Problems of Medical Health Workers during the COVID-19 Epidemic in China. Psychother Psychosom. 2020;89:242-50.

12. Pappa S, Ntella V, Giannakas T, et al. Prevalence of depression, anxiety, and insomnia among healthcare workers during the COVID-19 pandemic: A systematic review and meta-analysis. Brain Behav Immun. 2020;88:901-7.

13. Kang L, Ma S, Chen M, et al. Impact on mental health and perceptions of psychological care among medical and nursing staff in Wuhan during the 2019 novel coronavirus disease outbreak: A cross-sectional study. Brain Behav Immun. 2020;87:11-7.

14. Kroenke K, Spitzer RL, Williams JB. The PHQ-9: validity of a brief depression severity measure. $J$ Gen Intern Med. 2001;16:606-13.

15. Sari YE, Kokoglu B, Balcioglu $\mathrm{H}$, et al. Turkish reliability of the patient health questionnaire-9. Biomed Res. 2016;:Special Issue:S460-S462.

16. Beck AT, Epstein N, Brown G, et al. An inventory for measuring clinical anxiety: psychometric properties. $J$ Consult Clin Psychol. 1988;56:893-7.

17. Ulusoy M, Sahin NH, Erkmen H. Turkish Version of the Beck Anxiety Inventory: Psychometric Properties. J Cogn Psychother. 1998;12:163-72.

18. Buysse DJ, Reynolds CF 3rd, Monk TH, et al. The Pittsburgh Sleep Quality Index: a new instrument for psychiatric practice and research. Psychiatry Res. 1989;28:193-213

19. Wang S, Xie L, Xu Y, et al. Sleep disturbances among medical workers during the outbreak of COVID-2019. Occup Med (Lond). 2020;70:364-9.

20. Agargun MY, Kara H, Anlar O. Validity and reliability of the Pittsburgh Sleep Quality Index in Turkish sample. Turk Psikiyatri Derg. 1996;7:107-15.

21. Yesil A, Ergun U, Amasyalı C, et al. Validity and Reliability of the Turkish Version of the Professional Quality of Life Scale. Noro Psikiyatr Ars. 2010;47:111-7. 
22. Maunder R, Hunter J, Vincent L, et al. The immediate psychological and occupational impact of the 2003 SARS outbreak in a teaching hospital. CMAJ. 2003;168:1245-51.

23. Lee AM, Wong JG, McAlonan GM, et al. Stress and psychological distress among SARS survivors 1 year after the outbreak. Can J Psychiatry. 2007;52:233-40.

24. Korkmaz S, Kazgan A, Çekiç S, et al. The anxiety levels, quality of sleep and life and problem-solving skills in healthcare workers employed in COVID-19 services. J Clin Neurosci. 2020;80:131-6.

25. Huang Y, Zhao N. Generalized anxiety disorder, depressive symptoms and sleep quality during COVID-19 outbreak in China: a web-based crosssectional survey. Psychiatry Res. 2020;288:112954.

26. Lu YC, Shu BC, Chang YY, et al. The mental health of hospital workers dealing with severe acute respiratory syndrome. Psychother Psychosom. 2006;75:370-5.

27. McAlonan GM, Lee AM, Cheung V, et al. Immediate and sustained psychological impact of an emerging infectious disease outbreak on health care workers. Can J Psychiatry. 2007;52:241-7.

28. Que J, Shi L, Deng J, et al. Psychological impact of the COVID-19 pandemic on healthcare workers: a cross-sectional study in China. Gen Psychiatr. 2020;33:e100259.

29. Dimitriu MCT, Pantea-Stoian A, Smaranda AC, et al. Burnout syndrome in Romanian medical residents in time of the COVID-19 pandemic. Med Hypotheses. 2020;144:109972.

30. Kannampallil TG, Goss CW, Evanoff BA, et al. Exposure to COVID-19 patients increases physician trainee stress and burnout. PLoS One. 2020;15:e0237301.

31. Zerbini G, Ebigbo A, Reicherts P, et al. Psychosocial burden of healthcare professionals in times of COVID19 - a survey conducted at the University Hospital Augsburg. Ger Med Sci. 2020;18:Doc05.

32. Ruiz-Fernández MD, Ramos-Pichardo JD, IbáñezMasero $\mathrm{O}$, et al. Compassion fatigue, burnout, compassion satisfaction and perceived stress in healthcare professionals during the COVID-19 health crisis in Spain. J Clin Nurs. 2020;29:4321-30.

33. Mazza C, Ricci E, Biondi S, et al. A Nationwide Survey of Psychological Distress among Italian People during the COVID-19 Pandemic: Immediate Psychological Responses and Associated Factors. Int $J$ Environ Res Public Health. 2020;17(9):3165.

34. González-Sanguino C, Ausín B, Castellanos MÁ, et al. Mental health consequences during the initial stage of the 2020 Coronavirus pandemic (COVID-19) in Spain. Brain Behav Immun. 2020;87:172-6.

35. Özdin S, Bayrak Özdin Ș. Levels and predictors of anxiety, depression and health anxiety during COVID19 pandemic in Turkish society: The importance of gender. Int J Soc Psychiatry. 2020;66(5):504-11.

36. Hall H. The effect of the COVID-19 pandemic on healthcare workers' mental health. JAAPA. 2020;33:45-8.

37. Janati Idrissi A, Lamkaddem A, Benouajjit A, et al. Sleep quality and mental health in the context of COVID-19 pandemic and lockdown in Morocco. Sleep Med. 2020;74:248-53. 